\title{
Pengaruh Ujian Ulangan Harian Menggunakan Computer Based Test Terhadap Motivasi Belajar Siswa
}

\author{
Mohammad Lutfi Eko Nurseha $^{1}$, Arifin Nur Budiono ${ }^{2}$, Wahyuni ${ }^{3}$ \\ 1,2,3 Universitas Islam Jember
}

Email : lutfiekosmadata@gmail.com

\begin{abstract}
ABSTRAK
Dalam era pendidikan modern motivasi belajar dapat ditumbuhkan melalui bentuk ujian modern berbasis teknologi. Salah satu bentuk ujian modern yang digunakan yaitu menggunakan Computer Based Test (CBT). CBT atau ujian berbasis komputer ialah bentuk ujian tes yang dalam pelaksanaannya berbantuan komputer ataupun laptop sebagai media untuk melakukan ujian. Tujuan dari penelitian ini ialah guna mengetahui pengaruh ujian ulangan harian menggunakan CBT terhadap motivasi belajar siswa kelas XI SMAN 2 Tanggul. Penelitian ini ialah jenis penelitian kuantitatif memakai korelasi sederhana. Metode analisis data dari penelitian ini yakni menggunakan korelasi product moment dengan bantuan aplikasi Satatistica Product and Service Solution (SPSS) 20.0 dan teknik pengumpulan data yang digunakan adalah angket. Jumlah sampel sebanyak 159 menggunakan simple random sampling. Berdasarkan hasil penelitian menghasilkan taraf Sig sebesar 0,00 artinya hasil dari taraf Sig 0,00<0,05 bisa disimpulkan bahwa terdapat pengaruh signifikan ujian ulangan harian menggunakan CBT terhadap motivasi belajar siswa kelas XI SMAN 2 Tanggul.
\end{abstract}

Kata Kunci : Ulangan Harian, Computer Based Test (CBT); Motivasi Belajar

\begin{abstract}
In the era of modern education, learning motivation can be grown through modern technology-based examinations. One of the modern forms of examinations used is the Computer Based Test (CBT). Computer Based Test is a form of test which in its implementation, is assisted by a computer or laptop as a medium for conducting exams. This study aimed to determine the effect of daily exams using CBT on student motivation of 2 nd Grade at SMAN 2 Tanggul. This research type is a quantitative research using simple correlation. The data analysis method of this research uses product-moment correlation with the help of the Statistical Product and Service Solutions (SPSS) 20.0 application and the data collection technique used is a questionnaire. The number of samples was 159 using simple random sampling. Based on the results of the study, the Sig level was 0.00, meaning that the results of the Sig level were $0.00<0.05$, it could be concluded that the research results had a significant effect on daily examination using CBT on the learning motivation of 2 nd grade students at SMAN 2 Tanggul.
\end{abstract}

Keywords: Daily Examination, Computer Based Test (CBT); Learning Motivation

(C) 2021 Mohammad Lutfi Eko Nurseha, Arifin Nur Budiono, Wahyuni

Under the license CC BY-SA 4.0

Pedagogika.fip@ung.ac.id P-ISSN: 2086-4469 E-ISSN: 2716-0580 


\section{PENDAHULUAN}

Pendidikan memiliki peran penting pada pembentukan karakter peserta didik, perkembangan ilmu maupun mental yang diterapkan melalui kegiatan pembelajaran. Pada proses pembelajaran, motivasi juga sangat diperlukan, karena motivasi dalam belajar mempengaruhi dalam aktivitas pembelajaran serta bisa mewujudkan suasana belajar maupun proses pembelajaran yang baik dan kompeten dan mampu mengembangkan potensi yang dimilki peserta didik dalam menghadapi setiap perubahan yang terjadi akibat berkembangnya hasil pemikiran moderen dalam bidang ilmu pengetahuan khususnya teknologi.

Menurut Uno (2011:23) engemukakan bahwa motivasi ialah suatu bentuk kekuatan yang muncul dari dalam ataupun dari luar diri individu sehingga mampu menggerakkan individu itu untuk melakukan suatu hal yang sebelumnya telah ditetapkannya, antara lain: terdapatnya sebuah hasrat maupun keinginan supaya berhasil; terdapatnya sebuah dorongan maupun kebutuhan untuk belajar; terdapatnya sebuah cita-cita maupun harapan dimasa depan; terdapatnya sebuah penghargaan dalam belajar; terdapatnya sebuah aktivitas menarik pada belajar; terdapatnya sebuah lingkungan belajar yang kondusif sehingga dapat membuat seseorang merasakan kegiatan belajar yang nyaman.
Motivasi dan belajar ialah dua hal yang mutlak dibutuhkan oleh seseorang, dari keduanya merupakan saling berkaitan dan saling memberikan pengaruh. Belajar merupakan perubahan dari tingkah laku yang terbentuk denan cara berangsur atau bertahap dan bersifat permanen pada diri sesesorang, serta secara kognitif berlangsung sebagai hasil dari suatu penerapan serta penguatan yang didasari sebagai tujuan dalam mencapai tujuan tertentu. Apabila seseorang mempunyai serta mendapatkan motivasi yang sesuai dan tepat, yang terjadi adalah seseorang tersebut akan mengeluarkan kemampuan yang luar biasa sehingga apa yang menjadi tujuannya akan tercapai secara maksimal (Purwanto, 2004:60-61). Dengan adanya motivasi belajar maka akan membangkitkan kemampuan serta menumbuhkan semangat dalam mencapai prestasi dan mampu meningkatkan kemampuan dalam berfikir kritis.

Maslow (1970) menyebutkan bahwa motivasi belajar merupakan suatu stimulus dari external ataupun internal dari individu dalam mengaktualisasikan kebutuhannya secara subtansial sebagai bentuk perubahan perilaku atau keterampilan individu untuk berkontribusi pada kebutuhan diri sendiri/komunitas. Sejalan dengan hal tersebut berdasarkan Sardiman (2011:75) motivasi belajar ialah pengaruh psikis yang mempunyai sifat tidak berdasarkan 
PEDAGOGIKA

Volume 12 (Nomor 1) 2021

HaL. 21-31

kecerdasan atau nonintelektual. adapun komputer ialah bentuk ujian tes yang dalam peranannya yang khusus yaitu dalam pelaksanaannya berbantuan komputer menumbuhkan hasrat atau keinginan, ataupun laptop sebagai media guna perasaan bahagia serta semangat untuk melaksanakan ujian. Penyajian serta belajar. Dengan demikian motivasi harus pemilihan soal dengan CBT dilaksanakan dikembangkan berdasarkan pertimbangan dengan menginput data kedalam komputer dengan memahami dari perbedaan setiap sehingga masing-masing peserta yang individu. Secara umum seluruh manusia mengerjakan tes memperoleh paket soal yang membutuhkan motivasi untuk dapat giat berbeda-beda sesuai atas pengaturan dasar bekerja maupun belajar (Oemar Hamalik, pembuatan soal. CBT merupakan bentuk 2002:179).

Upaya pembelajaran yang berkaitan dengan motivasi belajar adalah sesuatu hal yang erat kaitannya dari peran siswa. Diantaranya belajar menjadi berarti bila peserta didik memahami maksud dan tujuan belajar, belajar menjadi mempunyai makna bila peserta didik dihadapkan untuk memecahkan permasalahan yang menantangnya, belajar menjadi mempunyai makna bila pendidik dapat memusatkan seluruh kemampuan psikis dan kognitif peserta didik pada program kegiatan tertentu ataupun khusus, serta belajar menjadi hal menantang bagi siswa apabila mampu memahami prinsip penilaian dan evaluasi terhadap tujuan dari belajar siswa itu sendiri.

Dalam era moderen seperti saat ini motivasi belajar dapat ditumbuhkan melalui bentuk ujian moderen berbasis teknologi. Salah satu bentuk ujian moderen yang digunakan yaitu memakai Computer Based Test (CBT). CBT atau ujian berbasis serangkaian pelaksanaan ujian atau tes yang menggunakan media komputer yang dihubungkan oleh jaringan internet dan mayoritas bentuk soalnya adalah obyektif atau pilihan ganda (Jimoh, 2012).

Berkaitan dengan hal tersebut ujian tes berbasis komputer juga diterapkan di SMAN 2 Tanggul. Awalnya ujian tes berbasis komputer hanya diterapkan untuk Ujian Nasional Berbasis Komputer (UNBK). Sedangkan ujian ulangan harian dan ujian ulangan semester yang diterapkan masih berbasis paper test dan belum seluruhnya berbasis komputer, sehingga ujian ulangan harian dan ujian semeseter berbasis komputer dilaksanakan secara bertahap. Ujian tes berbasis komputer yang diterapkan di SMAN 2 Tanggul meliputi UNBK, ujian ulangan harian dan ujian semester.

Sehingga untuk memanfaatkan dan memaksimalkan sarana prasarana pembelajaran yang tersedia dan menunjang proses pembelajaran serta menumbuhkan 
semangat dan motivasi belajar yang sesuai kurikulum 2013, yang menjelaskan bahwa proses akademik yang berfokus kepada peserta didik ataupun Student Center Learning melalui proses belajar mengajar yang bersifat kontekstual (Kemendikbud, 2013). Maka ujian ulangan harian berbasis komputer CBT yang serentak dilaksanakan mulai awal tahun ajaran 2019/2020, sementara UNBK pada tahun 2017 dimana bentuk ujian tersebut merupakan bentuk ujian yang mengawali ujian berbasis komputer atau CBT.

Berdasarkan dari hasil wawancara pada beberapa guru mata pelajaran serta beberapa peserta didik kelas XI SMAN 2 Tanggul, bahwa motivasi belajar siswa di kelas setelah diterapkannya ujian ulangan harian dengan media CBT cukup tinggi, hal tersebut diketahui dalam kelas siswa sering bertanya mengenai uijan CBT, permintaan siswa untuk belajar CBT tugas tugas terselesaikan tepat waktu dengan menggunakan flashsdisk sebagai pengumpulan tugas, arahan untuk belajar tes online menggunakan jaringan wifi sekolah yang antusias dilakukan siswa. Penyampaian materi serta dalam pelaksanaan ulangan harian dengan menggunakan media komputer menurut beberapa siswa tersebut adalah hal yang menambah motivasi dalam belajar dikelas, karena siswa merasakan variasi metode pembelajaran yang baru dan moderen. Disamping itu juga dapat diketahui antusias dan motivasi belajar siswa ditunjukkan dengan siswa yang mengikuti uji coba atau simulasi tes saat jam istirahat.

CBT difokuskan terhadap sekolah yang memiliki fasilitas sarana prasaran yang lengkap yaitu laboratorium komputer yang memadai dan sesuai standar. Sehingga dapat digunakan sekolah untuk melakasanakakan UNBK, ujian semester berbasis komputer, dan ujian ulangan harian berbasis komputer. Karakteristik dari ujian berbasis komputer CBT adalah bentuk soal yang muncul secara otomatis dilayar komputer peserta ujian, selanjutnya peserta ujian cukup memilih jawaban yang benar dan sesuai menggunakan mouse dari setiap komputer. Para peserta ujian berbasis komputer dapat secara langsung memilih jawaban yang dianggap benar dan sesuai benar pada layar komputer masing-masing, berbeda sekali dengan ujian yang masih bermedia keratas atau Paper Based Test (PBT) dimana peserta ujian diwajibkan untuk menghitamkan bulatan jawaban pada kertas lembar jawaban yang disediakan. Sistem skoring atau koreksi secara sistematis dilakukan oleh komputer. Dari ketiga jenis ulangan berbasis komputer tersebut diatas dalam proses dan pelaksanaanya adalah sama.

Dalam ujian ulangan harian berbasis komputer atau CBT hasil tes dapat segera diketahui, sehingga mereka dapat mengetahui 
dan mengukur kemampuan hasil belajar mereka secara langsung. Apabila nilai mereka rendah maka mereka harus lebih giat belajar lagi dan jika hasil tes tinggi atau memuaskan maka mereka harus mempertahankan serta meningkatkannya. Sehingga dapat ditarik kesimpulan bahwa tes berbasis komputer dapat mempengaruhi motivasi belajar mereka untuk lebih ditingkatkan.

Penelitian yang relevan sebelumnya, adalah penelitian yang dilaksanakan Novrianti (2014) yang memperlihatkan bahwa CBT layak dipakai selaku media alternatif guna memecahkan masalah penyelenggaraan evaluasi proses belajar mengajar. Faiqotul Himah (2016) dalam penelitiannya mengemukakan bahwa pengembangan CBT pada pelajaran Fisika memperlihatkan kevalidan logis serta empiris. Kuntum Khoiro Ummah (2019) dalam penelitiannya menghasilkan bahwa ada pengaruh yang signifikan diantara penyelenggaraan ujian nasional berbasis komputer kepada motivasi belajar peserta didik di SMAN 10 Surabaya Tahun ajaran 2018-2019.

Berdasarkan dari uraian diatas maka dimungkinkan bahwa ujian ulangan harian dengan media CBT yang yang diterapkan di SMAN 2 Tanggul berpengaruh terhadap proses pembelajaran yang lebih moderen, efektif, efisien serta dapat meningkatkan motivasi belajar. Mengingat apabila ditelaah, ujian ulangan harian berbasis komputer atau CBT dapat mengurangi biaya, waktu dalam pengkoreksian soal, serta dapat memberikan pengalaman pada siswa dalam pelaksanaan pembelajaran yang moderen maupun untuk mengikuti ujian tes di perguruan tinggi.

Dari fenomena yang dijelaskan diatas peneliti bermaksud mengetahui pengaruh ujian ulangan harian menggunakan CBT terhadap motivasi belajar siswa pada kelas XI SMAN 2 Tanggul.

\section{METODE PENELITIAN \\ Rancangan Penelitian}

Penelitian ini ialah jenis penelitian kuantitatif dengan memakai pendekatan korelasi sederhana. Jenis penelitian ini adalah untuk mengetahui dan menentukan tingkat serta derajat suatu hubungan antara sepasang variabel atau bivariat. Menurut Emzir (2010:48) merupakan suatu bentuk rancangan tahap awal dalam penelitian yang dilaksanakan untuk prosoes penelitian selanjutnya yang mendeskripsikan keterkaitan antar dua variabel agar menghasilkan data yang lebih valid dan kompleks.

\section{SUMBER DATA}

\section{Populasi Dan Sampel}

Berdasarkan pendapat Sugiyono (2012:80) populasi merupakan suatu wilayah umum yang terdiri dari sekumpulan objek yang berkriteria tertentu yang telah ditetapkan dari peneliti yang mempunyai tujuan supaya dipelajari sehingga mendapatkan sebuah 
PEDAGOGIKA

Volume 12 (Nomor 1) 2021

HaL. 21-31

kesimpulan dalam proses penelitian. tempat, populasi dan sampel penelitian di Kuantitas populasi dalam penelitian sebanyak SMAN 2 Tanggul pada kelas XI. Jumlah 299 siswa sesuai induk data siswa kelas XI siswa di kelas XI SMAN 2 Tanggul sejumlah SMAN 2 Tanggul. Selanjutnya teknik 300 siswa yang terbagi menjadi 9 kelas yaitu pengambilan objek sampel dari jumlah kelas XI IPS 1, XI IPS 2, XI MIPA 1, XI populasi memakai teknik Simple Random Sampling, yakni pemilihan objek sampel secara acak. Sedangkan penentuan jumlah sampel pada populasi menggunakan tabel Krejcie dan didapatkan sampel sebanyak 159 siswa.

\section{TEKNIK PENGUMPULAN DATA}

Teknik pengumpulan data dalam penelitian ini memakai observasi serta angket. Jenis observasi yang dilakukan pada penelitian ini yakni menggunakan teknik obesrvasi nonpartisipan yang berarti peneliti tidak terlibat dengan langsung dilapangan dan dapat dikatakan peneliti hanya mengamati observan dari kejauhan. Tujuan dari observasi ini guna mendapatkan data terkait motivasi belajar peserta didik terhadap pengaruh ujian ulangan harian berbasis komputer (CBT).

\section{HASIL DAN PEMBAHASAN}

MIPA 2, XI MIPA 3, XI MIPA 4, XI MIPA 5, XI MIPA 6, XI MIPA 7. Pada penelitian ini, peneliti memakai 8 kelas untuk penelitian dan satu kelas digunakan untuk pengujian validitas angket yakni kelas XI IPA 7 yang mempunyai jumlah 35 siswa. Selanjutnya, penelitian dilakukan melalui populasi sebanyak 264 siswa dengan pengambilan sampel berdasarkan tabel kretjie sehingga diperoleh sampel sebanyak 159 siswa yang diambil secara acak di tiap kelas.

\section{Hasil Uji Validitas}

Dalam pengujian validasi angket menggunakan aplikasi Satatistica Product and Service Solution (SPSS) 20.0 yang dilakukan pada siswa kelas XI MIPA 7 yang mempunyai jumlah 35 siswa. Berdasarkan prosentase angket motivasi belajar dan Computer Based Test (CBT), sebagai berikut

\section{Hasil Penelitian}

\section{Responden}

Responden pada penelitian ini sebagai halnya yang sudah dipaparkan di BAB Metode Penelitian, yakni peneliti menetapkan

Tabel 1. Prosentase Skor Computer Based Test (CBT)

\begin{tabular}{c|c}
\hline Presentase Skor & Kriteria \\
\hline $0 \%$ & Rendah \\
$84,3 \%$ & Sedang \\
$15,7 \%$ & Tinggi \\
\hline
\end{tabular}


Tabel 2. Prosentase Skor Motivasi Belajar

\begin{tabular}{c|c}
\hline Presentase Skor & Kriteria \\
\hline $0 \%$ & Rendah \\
$53,5 \%$ & Sedang \\
$46,5 \%$ & Tinggi \\
\hline Korelasi Variabel X Dan Y & hubungannya semakin lemah. Hasil hitung
\end{tabular}

Nilai korelasi variabel (x) diperoleh 23162 dan (y) diperoleh 16026, selanjutnya nilai koefisien korelasi $\left(\mathrm{x}^{2}\right)$ diperoleh 3414768 dan $\left(y^{2}\right)$ 1642444. Dan untuk total nilai variabel (x dikali y) diperoleh 2345594.

\section{Uji Korelasi Product Moment}

Uji Pearson Product Moment yakni satu diantara dari sejumlah jenis pengujian korelasi yang dipakai guna mengetahui derajat keeratan hubungan dua variabel yang mempunyai skala interval ataupun rasio, yang mana melalui pengujian tersebut akan mengembalikan nilai koefisien korelasi yang memiliki nilai dengan rentang diantara $-1,0$ dan 1. Nilai -1 mempunyai arti bawah ada korelasi negatif yang sempurna, 0 mempunyai arti bahwa tidak terdapat korelasi serta 1 mempunyai arti bahwa terdapat korelasi positif yang sempurna.

Nilai koefisien korelasi yang mempunyai rentang diantara $-1,0$ dan 1 itu bisa diambil kesimpulan bahwa bila semakin mendekati nilai 1 ataupun -1 maka hubungannya semakin erat, sementara itu bila semakin mendekati 0 maka menggunakan rumus product moment yakni seperti berikut:

$$
\begin{gathered}
\mathrm{r}_{\mathrm{Xy}}=\frac{\mathrm{N} \sum \mathrm{XY}-\sum \mathrm{X} \sum \mathrm{Y}}{\sqrt{\left\{\mathrm{N} \sum \mathrm{X}^{2}-\left(\sum \mathrm{X}\right)^{2}\right\}\left\{\mathrm{N} \sum \mathrm{Y}^{2}-\left(\sum \mathrm{Y}\right)^{2}\right\}}} \\
=\frac{159 \times 2345594-23162 \times 16026}{\sqrt{\left\{159 \times 3414768-23162^{2}\right\}\left\{159 \times 1642444-16026^{2}\right\}}} \\
=\frac{372949446-371194212}{\sqrt{\{542948112-536478244\}\{261148596-256832676\}}} \\
=\frac{1755234}{\sqrt{\{6469868\}\{4315920\}}} \\
=0,332162551
\end{gathered}
$$

Berdasarkan hasil penghitungan memakai rumus product moment diatas didapatkan $\mathrm{r}$ hitung sejumlah 0,332 dengan sampel 159 pada taraf signifikasi 5\% r tabel diperoleh 0,148. Dari hasil tersebut diketahui r hitung > dari r tabel yakni 0,332 > 0,148. Maka dengan demikian hipotesis $\mathrm{Ha}$ diterima : ada pengaruh ujian ulangan harian menggunakan CBT terhadap motivasi belajar siswa kelas XI SMAN 2 Tanggul, dan Ho ditolak. 


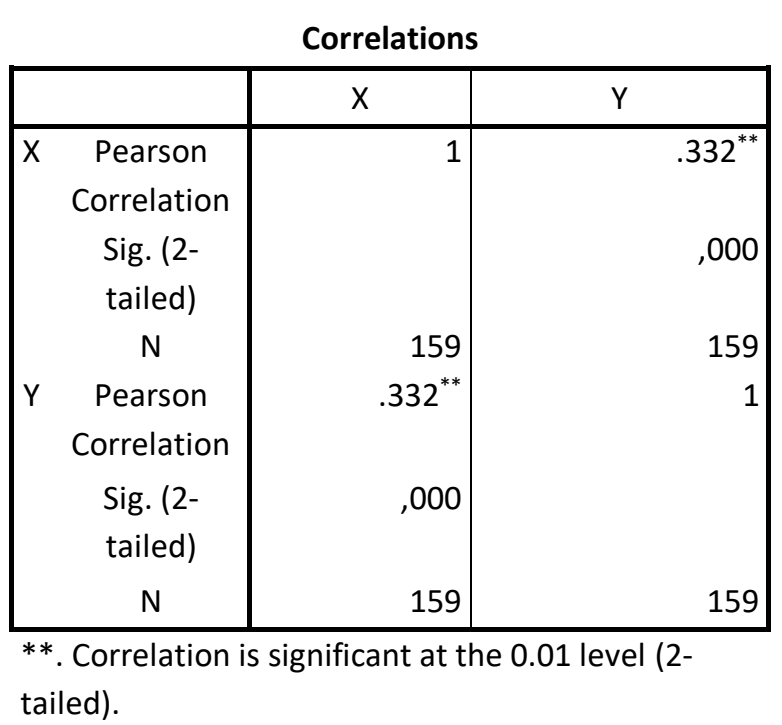

Dari hasil uji $r$ hitung diatas bisa dideskripsikan terkait nilai koefisien korelasi pengujian product moment serta makna keeratan pada suatu uji analisis data yakni hasil $r$ hitung 0,332 terletak diantara nilai koefisien $0,2<0,4$. Sehingga dapat disimpulkan bahwa terdapat korelasi namun hubungannya rendah atau lemah.

\section{Uji T}

Selanjutnya guna melakukan pengujian terhadap signifikasi hubungan yang didapatkan berlaku untuk semua populasi sejumlah 159 siswa, maka dipakai uji signifikasi Uji t. Dengan menggunakan nilai $r$ pearson yang diperoleh guna menentukan $t$ hitung, seperti di bawah ini :

$$
\begin{aligned}
\text { Uji t } & =\frac{r \sqrt{n-2}}{\sqrt{1-r^{2}}} \\
& =\frac{0,332 \sqrt{159-2}}{\sqrt{1-0,332^{2}}} \\
& =\frac{0,332 \times 12,5299640}{\sqrt{1-0,332}} \\
& =\frac{0,332 \times 12,5299640}{\sqrt{0,889776}}
\end{aligned}
$$

$$
\begin{aligned}
& =\frac{4,159948048}{0,94327938} \\
& =4,41009115
\end{aligned}
$$

Nilai t hitung kemudian dilakukan perbandingan terhadap nilai $t$ tabel taraf kesalahan $5 \%$ uji 2 pihak serta $\mathrm{dk}=\mathrm{N}-2=$ $159-2=157$ diperoleh nilai $\mathrm{t}$ tabel $=1,97519$.

. Dari hasil tersebut diketahui $r$ hitung $>$ dari r tabel yakni 4,410 > 1,975. Maka dengan begitu bisa diambil kesimpulan ada pengaruh yang signifikan ujian ulangan harian menggunakan CBT terhadap motivasi belajar siswa kelas XI SMAN 2 Tanggul.

Dari hasil tabel diatas disimpulkan pengaruh ujian ulangan harian menggunakan CBT terhadap motivasi belajar siswa kelas XI SMAN 2 Tanggul yang telah dibuktikan dengan penghitungan $t$ hitung dan diperkuat dengan Uji t untuk taraf signifikasi data dengan bantuan aplikasi SPSS 20.0 menghasilkan menghasilkan taraf Sig sebesar 0,00 yang artinya hasil dari taraf Sig kurang daripada $0,05(0,00<0,05)$ hipotesis Ha diterima dan Ho ditolak yang artinya dalam hasil penelitian ini terdapat pengaruh ujian ulangan harian menggunakan CBT terhadap motivasi belajar siswa kelas XI SMAN 2 Tanggul.

\section{Pembahasan}

Penelitian ini membahas sebuah jenis penelitian korelasi berdasarkan fenomena yang diangkat dari tempat penelitian, dan menjadi sebuah keterkaitan antara alat 
elektronik digital pengolah data atau komputer dengan motivasi belajar siswa. Jika ditinjau secara umum pada awalnya komputer hanya digunakan sebagai media pembantu manusia untuk menghitung dan mengolah data serta mencetak data yang telah dihitung dan diolah tersebut. Begitu pula dengan motivasi belajar apabila dikaitkan dengan komputer seperti tidak ada sebuah keterkaitan ataupun hubungan yang relevan. Namun yang dimaksud peniliti dalam pembahasan ini adalah keterkaitan antara ujian ulangan berbasis komputer Computer Based Test (CBT) dengan motivasi belajar. Sehingga secara garis besar penelitian ini bermaksud mencaritahu sebuah pengaruh ujian ulangan berbasis komputer terhadap motivasi belajar.

Dalam bukunya A. M (2014:89-91) menjelaskan, ada dua macam motivasi belajar yakni motivasi intrinsik serta motivasi ekstrinsik. Dalam penelitian ini variabel ujian ulangan berbasis komputer Computer Based Test (CBT) merujuk pada motivasi ekstrinsik. Pendapat tersebuat sejalan dengan pendapat dari Hamzah B. Uno (2011:23) yang menjelaskan motivasi belajar merupakan dorongan dari internal maupun eksternal kepada siswa yang sedang belajar guna memunculkan perilaku secara umum yang mendukung dalam proses belajar. Dimana motivasi belajar muncul karena pengaruh dari faktor eksternal yaitu ujian CBT.

Berlandaskan dari hasil penelitian yang dilangsungkan pada tanggal 25 hingga 31 Oktober 2020 di SMAN 2 Tanggul. Dimana angket ditujukan terhadap 159 sampel pada kelas XI, hasil prosentase skor angket Computer Based Test (CBT) menunjukkan $84,3 \%$ berkategori sedang dan $15,7 \%$ berkategori tinggi. Sedangkan prosentase skor angket motivasi belajar menunjukkan $53,5 \%$ bekategori sedang dan $46,5 \%$ berkategori tinggi dan tidak ada prosentase rendah diantara keduanya. Artinya hasil prosentase skor angket dapat mendukung ke arah adanya pengaruh Computer Based Test (CBT) terhadap motivasi belajar.

Hasil penelitaian diatas, diperkuat dengan hasil penelitian terdahulu yang Novrianti (2014) yang memperlihatkan bahwa CBT layak dipakai selaku media alternatif guna memecahkan masalah penyelenggaraan evaluasi proses belajar mengajar. Faiqotul Himah (2016) dalam penelitiannya mengemukakan bahwa pengembangan CBT pada pelajaran Fisika memperlihatkan kevalidan logis serta empiris. Kuntum Khoiro Ummah (2019) dalam penelitiannya menghasilkan bahwa ada pengaruh yang signifikan diantara penyelenggaraan ujian nasional berbasis komputer kepada motivasi belajar peserta 
didik di SMA Negeri 10 Surabaya Tahun ajaran 2018-2019. Sehingga dapat disimpulkan terdapat pengaruh ujian ulangan harian menggunakan CBT terhadap motivasi belajar siswa kelas XI SMAN 2 Tanggul.

Berdasarkan hasil penelitian dapat disimpulkan pengaruh ujian ulangan harian menggunakan CBT terhadap motivasi belajar siswa kelas XI SMAN 2 Tanggul yang telah dibuktikan dengan penghitungan $t$ hitung dan diperkuat dengan Uji t untuk taraf signifikasi data dengan bantuan aplikasi SPSS 20.0 menghasilkan menghasilkan taraf Sig sebesar 0,00 yang artinya hasil dari taraf Sig kurang daripada $0,05(0,00<0,05)$ sehingga hipotesis Ha diterima serta Ho ditolak yang berarti dalam hasil penelitian ini terdapat pengaruh signifikan ujian ulangan harian menggunakan CBT terhadap motivasi belajar siswa kelas XI SMAN 2 Tanggul.

\section{SIMPULAN}

Bersumber pada hasil penelitian yang sudah dilangsungkan maka bisa diambil kesimpulan bahwa ada pengaruh ujian ulangan harian menggunakan CBT terhadap motivasi belajar siswa kelas XI SMAN 2 Tanggul. Dimana data hasil penelitian telah dibuktikan melalui penghitungan $\mathrm{t}$ hitung dan diperkuat dengan $\mathrm{Uji} \mathrm{t}$ untuk taraf signifikasi data dengan bantuan aplikasi Satatistica Product and Service Solution (SPSS) 20.0 yang menghasilkan hipotesis Ha diterima serta Ho ditolak yang berarti dalam hasil penelitian ini terdapat pengaruh ujian ulangan harian menggunakan CBT terhadap motivasi belajar siswa kelas XI SMAN 2 Tanggul.

\section{REFERENSI}

Adha, Rachmadian. 2012. Penerapan Good Corporate Governance Lembaga Amil Zakat (Studi Kasus Pada Pos Keadilan Peduli Ummat Surabaya.

http://eprints.perbanas.ac.id/3276/1/ARTI KEL\%20ILMIAH.pdf

A.M, Sardiman. 2014. Interaksi dan Motivasi Belajar Mengajar. Jakarta: Rajawali Pers.

Azwar, S. (2007). Prosedur Penelitian Suatu Pendekatan Praktik. Jakarta: PT Rineka Cipta.

Dimyati dan Mudjiyono. 2013. Belajar dan Pembelajaran. Jakarta: Rineka Cipta.

Hadi, Samsul. (2013). Pengembangan Computerized Adaptive Test Berbasis Web. Yogyakarta: Aswaja Pressindo. http://journal.student.uny.ac.id/ojs/index. php/elektro/article/view/2184

Hamalik, Oemar. 2002. Perencanaan Anggaran Berdasarkan Pendekatan Sistem. Jakarta: Bumi Aksara.

Iskandsyah, Yodha (2017) Perancangan Core Engine Aplikasi Uji Kemampuan Programmer Berdasarkan Aspek Teknis Dan Kerjasama. Diploma thesis, Universitas Komputer Indonesia.repository .unikom.ac.id/10 November 2017

Jimoh, R. G., Shittu, A.J.K \& Kawu, Y. K. 2012. Students Perception of Computer Based Test (CBT) for Examining Undergraduate Chemistry Courses. Journal of Emerging Trends in Computing and Information Sciences, 3: 125-134 VOL. 3, NO. 2, February 2012

Jimoh, R. G., Shittu, A.J.K \& Kawu, Y. K. 2012 Journal of Emerging Trends in Computing and Information Sciences, 3: 125-134

Dewa Ayu Sri Agustina. Jurnal UNDHIRABALI. Volume 2, Nomor 1, Januari 2016

John Daintith, Computer Testing, A Dictionary of Computing, 2004, Retieved My31, 2011b. from Encyclopedia.com: http://www.encyclopedia.com/doc/1011computer-aided-testing.html

Lailly, N.R \& Wisudawati, A.W. 2015. Analisis Soal Tipe Higher Order Thinking Skill 
(HOTS) dalam Soal UN Kimia SMA Rayon B Tahun 2012/2013. Jurnal Kaunia Vol. XI No. 1, April 2015/1436:27-39 ISSN 2301-8550.

Maiziani, Fitri (2016). Efektivitas Computer Based Testing Sebagai Sarana Tes Hasil Belajar Jurnal Kiprah Vol. 4. No.1 Januari-Juni 2016

Maslow, A. H. (1970). Motivation and Personality (2nd ed.). New York: Harper and Row

Ngalim Purwanto. 2004. Prinsip-Prinsip dan Teknik Evaluasi Pengajaran. Bandung: Rosdakarya.

Novrianti. 2014. Pengembangan Computer Based Testing (CBT) sebagai Alternatif Teknik Penilaian Hasil Belajar. Jurnal Lentera Pendidikan.Vol. 17 no. 1 Juni 2014: 34-42

Purwanto, Ngalim. 2004. Psikologi Pendidikan. Bandung: Remaja Rosdakarya.

Nindia Harnes Prima Aidha. Jurnal BK UNESA. Volume 03. Nomor 01 Tahun 2013, $217<18$ November 2019>

Rosdiana, Rosdiana. (2018). Teknologi Pembelajaran Berbasis ICT (Penerapan Computer Based Test). Al-Khwarizmi: Jurnal Pendidikan Matematika dan Ilmu Pengetahuan Alam. 3. 31-38. 10.24256/jpmipa.v3i2.233

Saad.Al-Amri. (2007). Computer-based vs Paper-based Testing: Does the test administration mode matter.Proceedings of the BAAL Conference.

Computer Based Test (CBT) Sebagai Alternatif Instrumen Evaluasi Pembelajaran

Evi

Murniati

https://jurnal.fkip.uns.ac.id/index.php/snp e/article/view/10647

http://scholar.googleusercontent.com/sch olar?q=cache:mHrep3Y9nI0J:scholar.goo gle.com/\&hl=id\&as_sdt $=0,5$

Jurnal.fkip.uns. co.id Vol 3, No 1 (2017)

Sugiyono. (2012). Metode Penelitian Pendidikan

Pendekatan Kuantitatif, Kualitatif, dan $R \& D$. Bandung: Alfabeta

Sugiyono. (2018). Metode Penelitian Pendidikan

Pendekatan Kuantitatif, Kualitatif, dan

$R \& D$. Bandung: Alfabeta

Retno Pebriana Artikel, Pendidikan. 2017

Keunggulan Dan Kelemahan

PBT Dan CBS Pada Ujian Akhir https://stipgrahakaryamuarabulian.ac.id/2

017/05/22/keunggulan-dan-kelemahan-

pbt-dan-cbs-pada-ujian-akhir/

Uno, H. (2011). Teori Motivasi dan Pengukurannya. Jakarta: PT Bumi AksaraBandung

PT Remaja Rosdaka Karya. 